\title{
$\beta$-D-glucan inhibits endocrine-resistant breast cancer cell proliferation and alters gene expression
}

\author{
ZAINAB M.T. JAFAAR ${ }^{1 *}$, LACEY M. LITCHFIELD ${ }^{2 *}$, MARGARITA M. IVANOVA $^{2 *}$, \\ BRANDIE N. RADDE ${ }^{2}$, NUMAN AL-RAYYAN ${ }^{2,3}$ and CAROLYN M. KLINGE ${ }^{2}$ \\ ${ }^{1}$ Center of Biotechnology, Agricultural Research Directorate, Ministry of Science and Technology, Baghdad, Iraq; \\ ${ }^{2}$ Department of Biochemistry and Molecular Biology, Center for Genetics and Molecular Medicine, \\ University of Louisville School of Medicine, Louisville, KY 40292, USA
}

Received November 22, 2013; Accepted December 30, 2013

DOI: $10.3892 /$ ijo.2014.2294

\begin{abstract}
Endocrine therapies have been successfully used for breast cancer patients with estrogen receptor $\alpha(\mathrm{ER} \alpha)$ positive tumors, but $\sim 40 \%$ of patients relapse due to endocrine resistance. $\beta$-glucans are components of plant cell walls that have immunomodulatory and anticancer activity. The objective of this study was to examine the activity of $\beta$-D-glucan, purified from barley, in endocrine-sensitive MCF-7 versus endocrine-resistant LCC9 and LY2 breast cancer cells. $\beta$-D-glucan dissolved in DMSO but not water inhibited MCF-7 cell proliferation in a concentrationdependent manner as measured by BrdU incorporation with an $\mathrm{IC}_{50}$ of $\sim 164 \pm 12 \mu \mathrm{g} / \mathrm{ml}$. $\beta$-D-glucan dissolved in DMSO inhibited tamoxifen/endocrine-resistant LCC9 and LY2 cell proliferation with $\mathrm{IC}_{50}$ values of $4.6 \pm 0.3$ and $24.2 \pm 1.4 \mu \mathrm{g} / \mathrm{ml}$, respectively. MCF-10A normal breast epithelial cells showed a higher $\mathrm{IC}_{50} \sim 464 \mu \mathrm{g} / \mathrm{ml}$ and the proliferation of MDA-MB231 triple negative breast cancer cells was not inhibited by $\beta$-D-glucan. Concentration-dependent increases in the BAX/ BCL2 ratio and cell death with $\beta$-D-glucan were observed in MCF-7 and LCC9 cells. PCR array analysis revealed changes in gene expression in response to 24-h treatment with 10 or $50 \mu \mathrm{g} / \mathrm{ml} \beta$-D-glucan that were different between MCF-7 and LCC9 cells as well as differences in basal gene expression between the two cell lines. Select results were confirmed by
\end{abstract}

Correspondence to: Dr Carolyn M. Klinge, Department of Biochemistry and Molecular Biology, Center for Genetics and Molecular Medicine, University of Louisville School of Medicine, Louisville, KY 40292, USA

E-mail: carolyn.klinge@louisville.edu

${ }^{*}$ Contributed equally

Present address: ${ }^{3}$ Department of Pharmacology and Toxicology, University of Louisville School of Medicine, Louisville, KY 40292, USA

Key words: endocrine-resistance, estrogen receptor, estradiol, tamoxifen, PCR array, transcription quantitative real-time PCR demonstrating that $\beta$-D-glucan increased RASSF1 expression in MCF-7 cells and IGFBP3, $C T N N B 1$ and ER $\beta$ transcript expression in LCC9 cells. Our data indicate that $\beta$-D-glucan regulates breast cancer-relevant gene expression and may be useful for inhibiting endocrineresistant breast cancer cell proliferation.

\section{Introduction}

Acquired resistance to antiestrogen or aromatase inhibitor therapy affects $\sim 40-50 \%$ of patients whose breast tumors are estrogen receptor $\alpha(\mathrm{ER} \alpha)$-positive (1). Multiple mechanisms contribute to endocrine resistance and new therapies are needed to prevent endocrine resistance and treat these patients (2).

(1-3) $\beta$-D-glucans are diverse polysaccharides derived from plant cell walls composed of D-glucose monomers linked by (1-3) $\beta$-glycosidic bonds. The activities of $\beta$-glucans have been studied in vivo and in vitro (3). When ingested in plant materials, $\beta$-glucans are absorbed in the small intestine and taken up by macrophages. $\beta$-glucans are considered to be 'biological response modifiers' since they exhibit immunomodulatory, wound-healing, antiviral, antibacterial, anti-coagulatory and antitumoral activities (4). Because of their size, $\beta$-glucans work by binding to cell surface receptors (5). $\beta$-glucans act on several immune receptors, e.g., Dectin-1, complement receptor (CR3), scavenger receptors (SR), lactosylceramide (LacCer), and toll-like receptors, e.g., TLR-2/6, and trigger responses in macrophages, neutrophils, monocytes, natural killer cells, and dendritic cells in vitro $(5,6)$. $\beta$-glucans themselves had no direct cytotoxic effects on a panel of common cancer cell lines including carcinoma, sarcoma and blastoma cells (6).

Cell inhibitory activities of $\beta$-glucans in cancer cells in vitro have also been reported. A water-soluble $\beta$-glucan extract from the mycelia of Poria cocos was reported to inhibit the viability (MTT assay) of MCF-7 breast cancer cells with an $\mathrm{IC}_{50}$ of $400 \mu \mathrm{g} / \mathrm{ml}$ and to decrease cyclin D1 and cyclin E protein expression (7). The goal of this study was to examine the effect of a purified preparation of (1-3) $\beta$-D-glucan on the growth of endocrine-sensitive, estrogen receptor $\alpha(\operatorname{ER} \alpha)^{+}$ MCF-7 cells compared to normal breast epithelial $\left(E R \alpha^{-}\right)$ 
MCF-10A cells; estradiol $\left(\mathrm{E}_{2}\right)$-independent, tamoxifen (TAM) and fulvestrant-resistant, ER $\alpha^{+} \mathrm{LCC} 9(8,9)$ and LY2 $(10,11)$ cells; and 'triple negative/basal-like' MDA-MB-231 (12) cells. Additionally, we examined the effect of $\beta$-D-glucan on the expression of a set of genes implicated in breast cancer in MCF-7 and LCC9 cells using a PCR array. While not affecting MCF-10A normal breast epithelial cell proliferation, our results indicate that $\beta$-D-glucan inhibits breast cancer cell proliferation and modulates gene expression independent of ER $\alpha$ activity and may be useful for inhibiting endocrine-resistant breast cancer cell proliferation.

\section{Materials and methods}

Cells. MCF-7 and MDA-MB-231 human breast cancer cells were purchased from ATCC (Manassas, VA, USA) and maintained in IMEM supplemented with 5\% fetal bovine serum (Atlanta Biologicals, Lawrenceville, GA, USA) and $1 \%$ penicillin/streptomycin (Mediatech, Manassas, VA, USA) (13). LCC9 (8) and LY2 (10) cell lines were derived from MCF-7 cells by cultivation with the anti-estrogens ICI 182,780 (Fulvestrant) and LY 117018 respectively, and were graciously provided as a gift by Dr Robert Clarke, Georgetown University. MCF-10A cells are immortalized normal human breast epithelial cells that were also purchased from ATCC and grown in DMEM/F12 supplemented with $5 \%$ horse serum, $20 \mathrm{ng} / \mathrm{ml}$ epidermal growth factor (EGF), $16.67 \mu \mathrm{g} / \mathrm{ml}$ insulin and $0.1 \%$ hydrocortisone (Sigma-Aldrich, St. Louis, MO, USA). Prior to treatment, the medium was replaced with phenol red-free IMEM supplemented with 5\% dextran-coated charcoal-stripped FBS (DCC-FBS) and $1 \%$ penicillin/streptomycin for $48 \mathrm{~h}$ (referred to as 'serumstarving').

Chemicals. Estradiol $\left(\mathrm{E}_{2}\right)$ and 4-hydroxytamoxifen (4-OHT) were purchased from Sigma-Aldrich. ICI 182,780 was from Tocris (Ellisville, MO, USA). $\beta$-D-glucan was purchased from Sigma (cat. no. G6513, purity $\sim 97 \%$ ). $\beta$-D-glucan was dissolved either in water or in DMSO (Sigma) by heating in a waterbath at $90^{\circ} \mathrm{C}$ for $4-5 \mathrm{~min}$. Once dissolved, the $\beta$-D-glucan stocks were stored at $-20^{\circ} \mathrm{C}$ until use. For all experiments, any effect(s) of DMSO were corrected in the calculations.

Cell proliferation and cell death assays. The cells were seeded at a density of 5,000 cells/well in 96-well plates and were incubated for $24 \mathrm{~h}$ in growth medium prior to treatment. To initiate the experiment, the medium was removed and cells were treated with different concentrations of $\beta$-D-glucan $(1-400 \mu \mathrm{g} / \mathrm{ml}$, as indicated in the Figures) and incubated for $72 \mathrm{~h}$. Medium and treatments were changed after the first $48 \mathrm{~h}$ of incubation. For certain experiments, the cells were also treated with $100 \mathrm{nM}$ or $1 \mu \mathrm{M} 4-\mathrm{OHT}$ and $\beta$-D-glucan $(10,50$ and $100 \mu \mathrm{g} / \mathrm{ml})$ to examine the potential synergistic effect of $\beta$-D-glucan with 4-OHT. Cell proliferation was determined after $72 \mathrm{~h}$ by measuring BrdU incorporation using an ELISA kit from Roche Applied Science (cat. 11647229001 , Indianapolis, IN, USA) according to the manufacturer's instructions. IC $_{50}$ values were calculated using Excel.
Cell death was examined using the Live/Dead Viability/ Cytotoxicity assay (Invitrogen), which determines intracellular esterase activity and plasma membrane integrity. In brief, $3 \times 10^{5}$ cells were incubated with DMSO or increasing concentrations of $\beta$-D-glucan for $72 \mathrm{~h}$. Cells were stained with the live and dead reagent $[2 \mu \mathrm{mol} / 1$ ethidium homodimers-1 (Eth-1) and $1 \mu \mathrm{mol} / 1$ calcein-AM] and incubated at room temperature for $30 \mathrm{~min}$. Fluorescence was read at 530 and $645 \mathrm{nM}$. The Live/Dead cell assay controls and calculations for \% dead cells followed the manufacturer's protocol.

PCR arrays. MCF-7 or LCC9 cells were serum-starved, as above, for $48 \mathrm{~h}$ and then treated with DMSO (vehicle control), 10 or $50 \mu \mathrm{g} / \mathrm{ml} \beta$-D-glucan, $10 \mathrm{nM} \mathrm{E}_{2}$, or $100 \mathrm{nM}$ 4-OHT. Total RNA was extracted using RNeasy Mini kit (Qiagen, Valencia, CA, USA). RNA quality was examined by NanoDrop Spectroscopy and cDNA synthesis was performed using the RT2 PCR Array First Strand kit (SABiosciences, Qiagen). RT2 Profiler PCR Array Breast Cancer SABiosciences cat no. PAHS-131ZA-12 contains 84 genes commonly involved in the dysregulation of signal transduction and other biological processes during breast carcinogenesis and in breast cancer cell lines plus 5 housekeeping genes http://www.sabiosciences.com/rt_pcr_ product/HTML/PAHS-131Z.html. Breast cancer PCR arrays were performed according to the manufacturer's instructions. Data analysis was performed using the web-based analysis tool (www.sabiosciences.com/pcrarraydataanalysis.php), including fold change and cluster analyses.

Quantitative real-time PCR ( $q R T-P C R)$ analysis of $m R N A$ expression. Total RNA was isolated from MCF-7 or LCC9 cells after 24-h treatment with DMSO (vehicle control), $10 \mathrm{nME}_{2}, 100 \mathrm{nM} 4-\mathrm{OHT}$, or 10 or $50 \mu \mathrm{g} / \mu \mathrm{l} \beta$-D-glucan with RNeasy Mini kit (Qiagen) according to the manufacturer's instructions. The quality and quantity of the isolated RNA was analyzed using NanoDrop spectroscopy. RNA $(1 \mu \mathrm{g})$ was reverse-transcribed using the High Capacity cDNA Reverse Transcription kit (Applied Biosystems, Carlsbad, CA, USA) and quantitation was performed using TaqMan primers and probes sets with TaqMan Gene Expression Master Mix (Applied Biosystems) and 18S was used for normalization. qRT-PCR was run using a ViiA7 Real-time PCR system (Applied Biosystems) with each reaction run in triplicate. Analysis and fold change were determined using the comparative threshold cycle $(\mathrm{Ct})$ method. The change mRNA expression was calculated as fold-change, i.e., relative to DMSO-treated cells (control).

Western blot analysis. Whole cell lysates were prepared from MCF-7 and LCC9 cells grown in phenol red-free IMEM $+5 \%$ DCC-stripped FBS for $48 \mathrm{~h}$ prior to addition of DMSO (vehicle control) or 10 or $50 \mu \mathrm{g} / \mathrm{ml} \beta$-D-glucan dissolved in DMSO for $24 \mathrm{~h}$. Whole cell extracts ( $30 \mu \mathrm{g}$ protein) were separated on $10 \%$ SDS-PAGE gels and the resulting western blot was probed with HC-20 ER $\alpha$ antibody (Santa Cruz Biotechnology, Santa Cruz, CA, USA). The PVDF membrane was stripped and re-probed for $\beta$-actin (Sigma) for normalization. Chemiluminescent bands were visualized on a Carestream Imager using Carestream Molecular Imaging software (New Haven, CT, USA). 


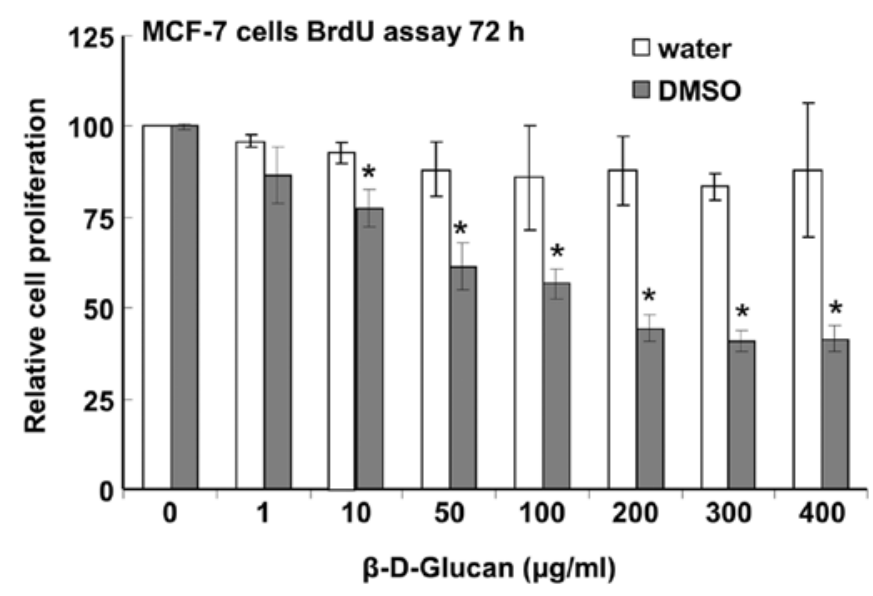

Figure 1. $\beta$-D-glucan dissolved in DMSO but not water inhibits MCF-7 cell proliferation. MCF-7 cells were incubated in phenol red-free IMEM $+5 \%$ DCC and the indicated concentrations of $\beta$-D-glucan dissolved in water or DMSO for a total of $72 \mathrm{~h}$ with a medium/treatment change after $48 \mathrm{~h}$. Values are the mean \pm SEM for 4 separate values in one experiment for $\beta$-D-glucan in water and 6 separate experiments (biological replicates) for $\beta$-D-glucan in DMSO. Values of $\beta$-D-glucan in DMSO were corrected for the inhibitory effect of DMSO on cell proliferation. ${ }^{*} \mathrm{p}<0.05$ vs. control (Student's t-test). The $\mathrm{IC}_{50}$ value for $\beta$-D-glucan in MCF-7 cells was $164 \mu \mathrm{g} / \mathrm{ml}$ (calculated in Excel).

Statistical analysis. Values are reported as \pm SEM. Student's t-test was used for comparisons between control and treatment. One-way ANOVA was used for multiple comparisons followed by Student-Newman-Keuls or Dunnett's post hoc tests using GraphPad Prism. Values with $\mathrm{p}<0.05$ were considered statistically significant.

\section{Results}

$\beta$-D-glucan dissolved in DMSO but not water inhibits MCF-7 cell proliferation. Batch-to-batch variability of extracts of $\beta$-glucans leads to problematic heterogeneity of effects and controversy regarding their significance as potential anticancer agents (14). To obviate this issue, we purchased $\beta$-D-glucan purified from barley from Sigma and tested its activity in breast cancer cells. There was no inhibition of MCF-7 cell proliferation when cells were treated with $\beta$-glucan dissolved in boiling water, but cells were inhibited with an $\mathrm{IC}_{50}$ of $\sim 164 \pm 12 \mu \mathrm{g} / \mathrm{ml}$ with $\beta$-glucan dissolved in DMSO (Fig. 1).

$\beta$-D-glucan inhibits MCF-10A, but not HEK-293 cell proliferation. Next, we examined if DMSO-solubilized $\beta$-D-glucan affected the growth of 'normal' cells using MCF-10A immortalized breast epithelial cells and HEK-293 cells (Fig. 2). $\beta$-D-glucan inhibited MCF-10A proliferation with an $\mathrm{IC}_{50}$ of $\sim 464 \mu \mathrm{g} / \mathrm{ml}$, but had no significant inhibitory effect on HEK-293 cells, although a somewhat 'U-shaped' response was detected, i.e., apparent inhibition at $10 \mu \mathrm{g} / \mathrm{ml}$ and stimulation at $100-400 \mu \mathrm{g} / \mathrm{ml}$.

$\beta$-D-glucan inhibits the proliferation of endocrine-resistant cells. The development of acquired resistance to tamoxifen and other endocrine agents is a major concern in breast cancer patients. We examined if DMSO-solubilized $\beta$-D-glucan

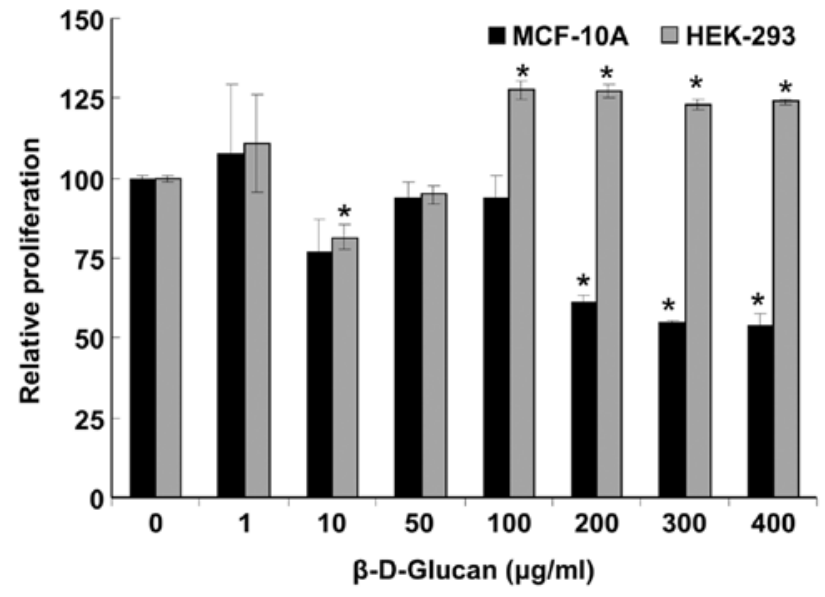

Figure 2. $\beta$-D-glucan inhibits MCF-10A but not HEK-293 cell proliferation. MCF-10A and HEK-293 cells were incubated in phenol red-free IMEM $+5 \% \mathrm{DCC}$ and the indicated concentrations of $\beta$-D-glucan dissolved in DMSO for a total of $72 \mathrm{~h}$ with a medium/treatment change after $48 \mathrm{~h}$. Values are the BrdU incorporation absorbances normalized to DMSO (zero) and are the mean \pm SEM for 4 separate values in one experiment. Values of $\beta$-D-glucan in DMSO were corrected for the inhibitory effect of DMSO on cell proliferation. * $\mathrm{p}<0.05$ vs. control (Student's t-test). The $\mathrm{IC}_{50}$ value for $\beta$-D-glucan in MCF-10A cells was $464 \mu \mathrm{g} / \mathrm{ml}$ (calculated in Excel).
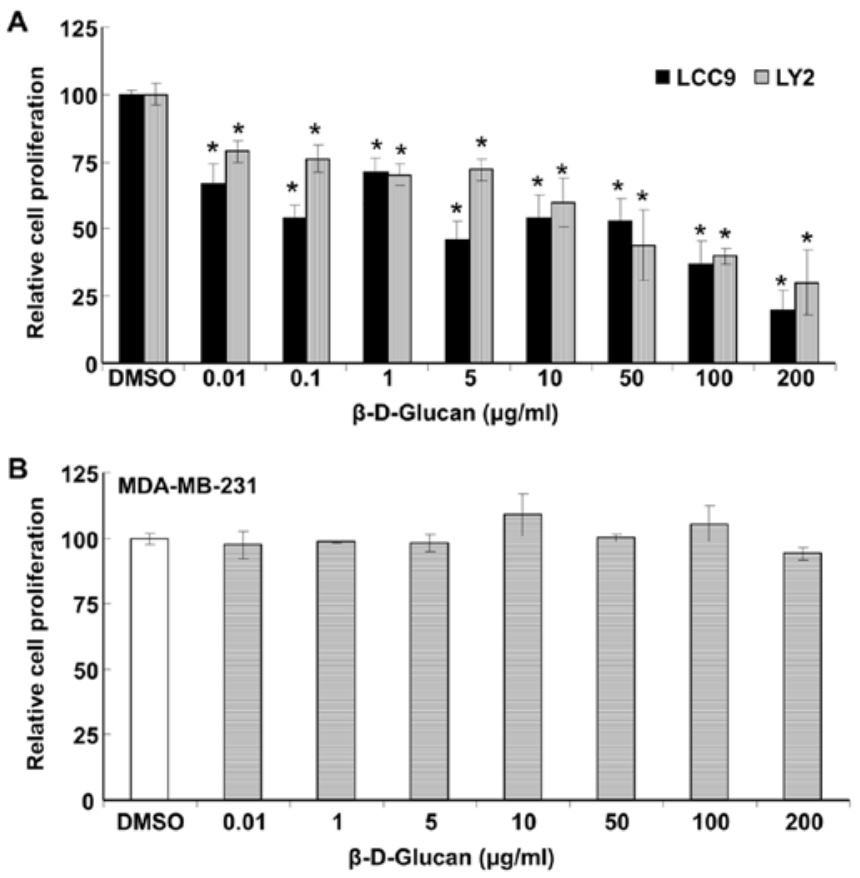

Figure 3. $\beta$-D-glucan inhibits the proliferation of endocrine-resistant breast cancer cells. LCC9 and LY2 endocrine-resistant breast cancer cells (A) and MDA-MB-231 triple negative breast cancer cells (B) were incubated in phenol red-free IMEM + 5\% DCC and the indicated concentrations of $\beta$-D-glucan dissolved in DMSO for a total of $72 \mathrm{~h}$ with a medium/treatment change after $48 \mathrm{~h}$. Values are the BrdU incorporation absorbances normalized to DMSO (zero) and are the mean \pm SEM for 3 separate experiments. Values of $\beta$-D-glucan in DMSO were corrected for the inhibitory effect of DMSO on cell proliferation. " $\mathrm{p}<0.05$ vs. control (Student's t-test).

inhibited the growth of LCC9 and LY2 endocrine-resistant breast cancer cells (Fig. 3A). $\beta$-D-glucan inhibited the proliferation of each cell line, with $\mathrm{IC}_{50}$ values of $4.6 \pm 0.3$ and $24.2 \pm 1.4 \mu \mathrm{g} / \mathrm{ml}$ for LCC9 and LY2, respectively. In contrast, 
A
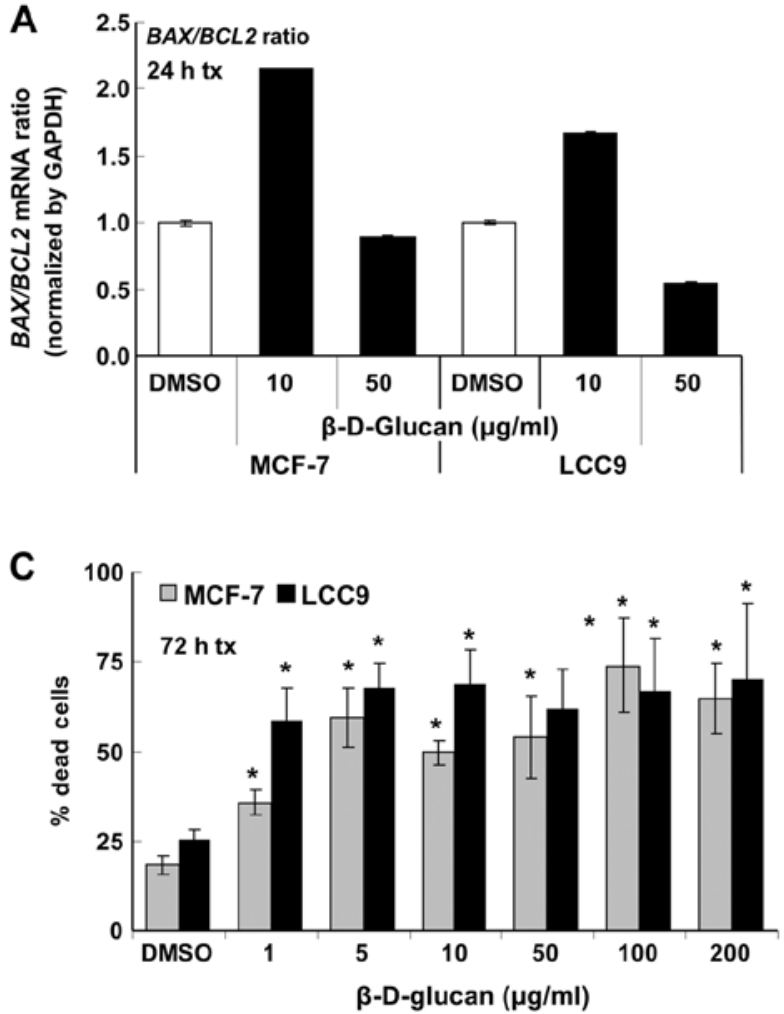

B

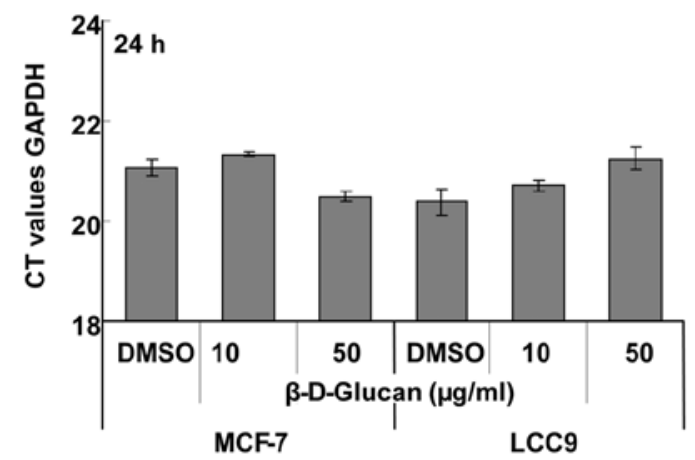

Figure 4. $\beta$-D-glucan increases apoptosis and cell death in MCF-7 and LCC9 cells. (A) MCF-7 tamoxifen-sensitive and LCC9 tamoxifen-resistant breast cancer cells were incubated in phenol red-free IMEM $+5 \% \mathrm{DCC}$ for $48 \mathrm{~h}$ prior to addition of the indicated concentrations of $\beta$-D-glucan dissolved in DMSO or DMSO as vehicle control for 24 h. BAX and BCL2 mRNA transcript expression was normalized by GAPDH (B) and the fold relative to DMSO (vehicle control) was set to one. (B) qPCR for GAPDH expression is given as CT values. For (A) and (B), the values are the average \pm SEM of triplicate determinations within one experiment. (C) MCF-7 and LCC9 cells were incubated in phenol red-free IMEM $+5 \%$ DCC and the indicated concentrations of $\beta$-D-glucan dissolved in DMSO or DMSO as vehicle control for $72 \mathrm{~h}$ with a medium/treatment change after $48 \mathrm{~h}$. Live/Dead Viability/Cytotoxicity assay was performed as described in Materials and methods. Values are the \% of dead cells measured by uptake of ethidium homodimer- 1 and fluorescence emission at 645 nm. Values are the average of 4 replicates within one experiment. "p<0.05 vs. control (Student's t-test).

$\beta$-D-glucan had no effect on MDA-MB-231 triple-negative/ basal-like breast cancer cells (Fig. 3B).

To examine the possible contribution of apoptosis to the observed decrease in MCF-7 and LCC9 cell viability with $\beta$-D-glucan treatment, we measured the expression of $B A X$ (pro-apoptotic) and BCL2 (anti-apoptotic) in MCF-7 and LCC9 cells treated with vehicle (DMSO), 10 or $50 \mu \mathrm{g} / \mathrm{ml}$ $\beta$-D-glucan (Fig. 4A). GAPDH mRNA transcript levels were not affected by $\beta$-D-glucan (Fig. 4B). An increased BAX/BCL2 is an indicator of apoptosis (15). As reported previously (16), basal BCL2 expression was higher in the endocrine-resistant LCC9 cells compared to parental, endocrine-sensitive MCF-7 cells (data not shown). $\beta$-D-glucan $(10 \mu \mathrm{g} / \mathrm{ml})$ increased the $B A X / B C L 2$ ratio in both cell lines, but that increase was not sustained at $50 \mu \mathrm{g} / \mathrm{ml} \beta$-D-glucan.

Live/Dead cell assays were performed to examine cell death through determination of intracellular esterase activity and plasma membrane integrity (Fig. 4C). The data show that $\beta$-D-glucan increases cell death in both MCF-7 and LCC9 cells with more death in LCC9 versus MCF-7 cells at $1 \mu \mathrm{g} / \mathrm{ml}$ $\beta$-D-glucan. There appears to be a saturation, with maximal $\sim 70 \%$ cell death in both cell lines. was extracted from the mushroom Schizophyllum commune by boiling in water showed no additive effect with TAM treatment in suppressing PCNA staining in DMBA-induced mouse mammary tumors, but inhibited TAM-induced PCNA staining in liver tumors of the same mice (17). We tested if $\beta$-D-glucan synergized with 4-OHT to inhibit MCF-7 endocrine-sensitive and LCC9 endocrine-resistant cell growth. There was no effect of $\beta$-D-glucan on the inhibition of MCF-7 cell growth by 4-OHT, nor was there any effect of 4-OHT on the inhibition of LCC 9 cell proliferation by $\beta$-D-glucan (Fig. 5).

$\beta$-D-glucan inhibits NRF-1 expression in MCF-7 cells. Nuclear respiratory factor-1 (NRF-1) is a master transcription factor regulating the transcription of nuclear genes controlling many aspects of mitochondrial function including respiration (18). Knockdown of NRF-1 in MCF-7 breast cancer cells using siRNA increases apoptosis and overexpression of NRF-1 inhibits 4-OHT-mediated apoptosis (19). We tested the hypothesis that the inhibition of MCF-7 cell proliferation and viability by $\beta$-D-glucan (Figs. 1 and 4 ) would be reflected in inhibition of NRF-1 expression. $\beta$-D-glucan rapidly inhibited NRF-1 transcription in a concentration-dependent manner without affecting 18S rRNA expression (Fig. 6). The rapid inhibition of NRF-1 transcription is commensurate with plasma membrane effects of $\beta$-D-glucan. 


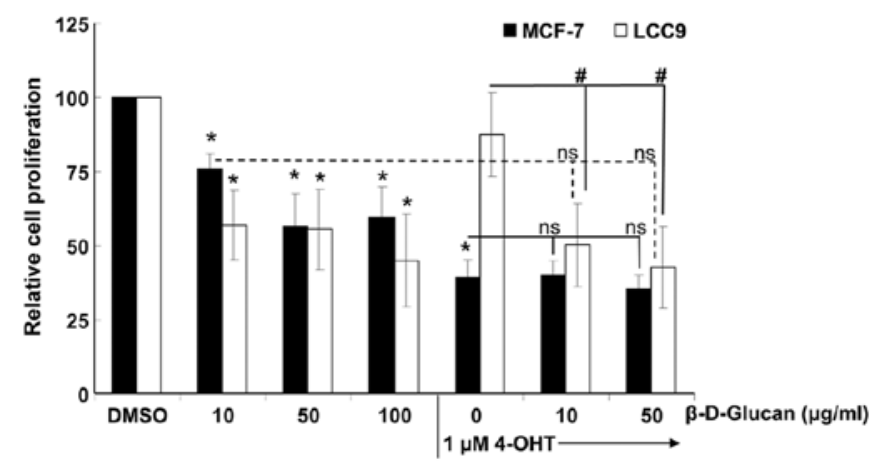

Figure 5. $\beta$-D-glucan does not synergize with 4-hydroxytamoxifen to inhibit cell proliferation. MCF-7 tamoxifen-sensitive and LY2 tamoxifen-resistant breast cancer cells were incubated in phenol red-free IMEM + 5\% DCC and the indicated concentrations of $\beta$-D-glucan dissolved in DMSO, $1 \mu \mathrm{M}$ $4-\mathrm{OHT}$, or the combination of $1 \mu \mathrm{M} 4-\mathrm{OHT}+10$ or $50 \mu \mathrm{g} / \mathrm{ml} \beta$-D-glucan, as indicated, for a total of $72 \mathrm{~h}$ with a medium/treatment change after $48 \mathrm{~h}$. Values are the BrdU incorporation absorbances normalized to DMSO (zero) and are the mean \pm SEM for 3 separate experiments. Values of $\beta$-D-glucan in DMSO were corrected for the inhibitory effect of DMSO on cell proliferation. " $\mathrm{p}<0.05$ vs. control. ${ }^{\#} \mathrm{p}<0.05$ vs. $1 \mu \mathrm{M} 4-\mathrm{OHT}$ alone (one-way ANOVA followed by Dunnett's post hoc test). ns, not statistically different from the same treatment in that cell line, i.e., dotted line indicates that the values for LCC9 with 10 or $50 \mu \mathrm{g} / \mathrm{ml} \beta$-D-glucan are not different from the values for LCC9 with $4-\mathrm{OHT}+10$ or $50 \mu \mathrm{g} / \mathrm{ml} \beta$-D-glucan.
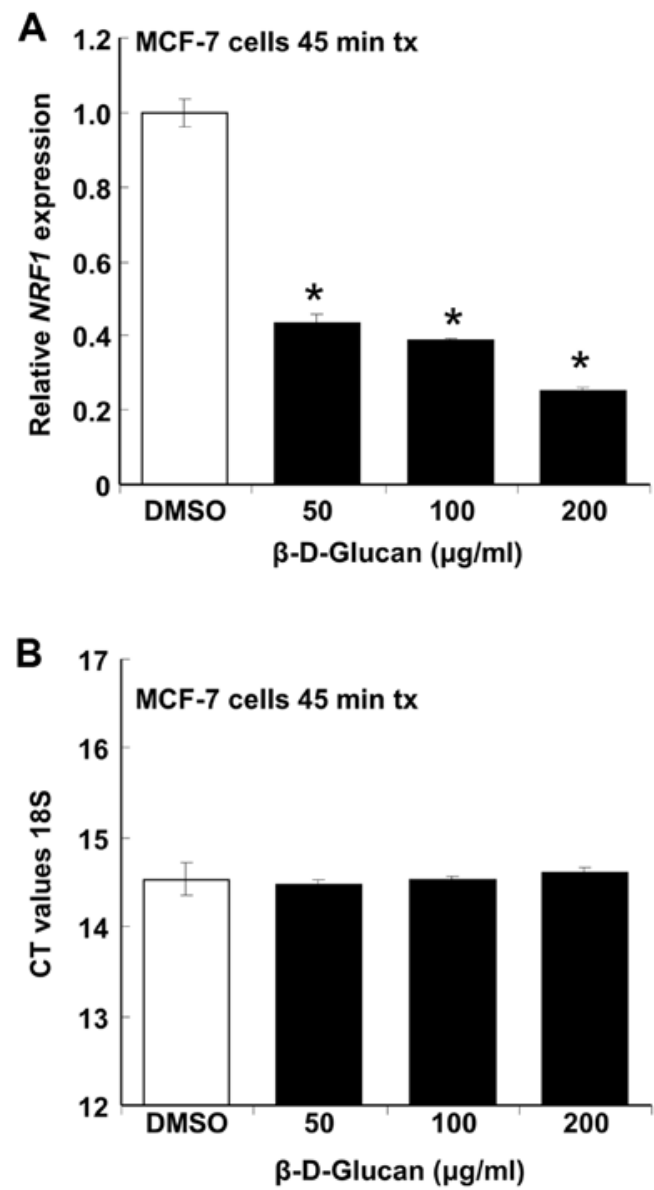

Figure 6. $\beta$-D-glucan rapidly inhibits $N R F 1$ expression in MCF-7 cells. MCF-7 cells were grown in phenol red-free IMEM + 5\% DCC for $48 \mathrm{~h}$ prior to addition of the indicated concentrations of DMSO-dissolved $\beta$-D-glucan for $45 \mathrm{~min}$. (A) qPCR for NRF1 mRNA expression was normalized to $18 \mathrm{~S}$ rRNA. ${ }^{*} \mathrm{p}<0.05$ vs. control (Student's t-test). (B) qPCR for $18 \mathrm{~S}$ expression is given as $\mathrm{CT}$ values.
Table I. Genes with decreased expression following treatment with $\beta$-D-glucan, $\mathrm{E}_{2}$ and/or 4-OHT in MCF-7 endocrinesensitive breast cancer cells.

\begin{tabular}{lcccr}
\hline Symbol & $\begin{array}{c}10 \mu \mathrm{g} / \mathrm{ml} \\
\beta \text {-D-glucan }\end{array}$ & $\begin{array}{c}50 \mu \mathrm{g} / \mathrm{ml} \\
\beta \text {-D-glucan }\end{array}$ & $\mathrm{E}_{2}$ & $4-\mathrm{OHT}$ \\
\hline AR & 1.1 & -1.2 & $\mathbf{- 2 . 1}$ & -1.2 \\
ATM & -1.3 & -1.6 & $\mathbf{- 4 . 3}$ & -1.9 \\
CCND2 & -1.4 & 1.0 & $\mathbf{- 2 . 1}$ & -1.0 \\
CDKNIC & $\mathbf{- 2 . 2}$ & $\mathbf{- 2 . 4}$ & $\mathbf{- 2 . 0}$ & -1.6 \\
CSF1 & -1.1 & -1.2 & $\mathbf{- 2 . 4}$ & 1.1 \\
CTNNB1 & -1.0 & $\mathbf{- 4 . 3}$ & -1.2 & 1.0 \\
ERBB2 & -1.6 & -1.9 & $\mathbf{- 2 . 2}$ & 1.4 \\
GRB7 & -1.6 & -1.7 & $\mathbf{- 2 . 4}$ & 1.0 \\
IGFBP3 & -1.7 & $\mathbf{- 2 . 2}$ & -1.7 & 1.2 \\
MUC1 & $\mathbf{- 2 . 1}$ & -1.4 & -1.4 & -1.0 \\
NOTCH1 & -1.6 & -1.0 & $\mathbf{- 2 . 3}$ & -1.5 \\
PLAU & $\mathbf{- 2 . 3}$ & $\mathbf{- 2 . 4}$ & -1.5 & 1.1 \\
RARB & $\mathbf{- 3 . 5}$ & $\mathbf{- 2 . 2}$ & $\mathbf{- 3 . 3}$ & $\mathbf{- 2 . 3}$ \\
SLIT2 & -1.5 & $\mathbf{- 2 . 7}$ & $\mathbf{- 3 . 0}$ & 1.5 \\
SNAI2 & $\mathbf{- 2 . 4}$ & -1.5 & -1.1 & 1.9 \\
\hline
\end{tabular}

Values in bold are greater than the 2-fold cut off in the Breast Cancer PCR array (PAHS-131Z, SABiosciences).

$\beta$-D-glucan affects breast cancer gene expression in a cell type-dependent manner. To identify other potential breast cancer-associated genes regulated by $\beta$-D-glucan, we performed PCR array analysis on 84 genes commonly dysregulated during breast carcinogenesis and in breast cancer cell lines (Breast Cancer PCR array PAHS-131Z, SABiosciences). For these experiments, MCF-7 or LCC9 cells were serum-starved for $48 \mathrm{~h}$ in phenol red-free medium and then treated in duplicate with DMSO (vehicle control), $10 \mathrm{nM} \mathrm{E}_{2}, 100 \mathrm{nM} 4-\mathrm{OHT}$, or 10 or $50 \mu \mathrm{g} / \mathrm{ml} \beta$-D-glucan for $24 \mathrm{~h}$. Using a 2 -fold cut off, $\beta$-D-glucan altered the expression of 17 genes in MCF-7 cells: 8 downregulated and 9 upregulated. Some, but not all, genes showed a dose-dependent effect of $\beta$-D-glucan, e.g., IGFBP3 showed a greater decrease with 50 than $10 \mu \mathrm{g} / \mathrm{ml} \beta$-D-glucan (Table I). In the group of genes with increased expression in MCF-7 with $\beta$-D-glucan, some $\beta$-D-glucan regulated genes had a similar expression pattern as with $E_{2}$ treatment and others showed similarity with 4-OHT treatment (Table II). $\beta$-D-glucan altered the expression of 8 genes in LCC9: 3 downregulated and 5 upregulated (Tables III and IV). $E_{2}$ altered the expression of 17 genes in MCF-7: 9 downregulated and 8 upregulated. 4-OHT altered the expression of 8 genes in MCF-7: 1 downregulated and 7 upregulated. $\mathrm{E}_{2}$ altered the expression of 5 genes in LCC9: 2 downregulated and 3 upregulated. 4-OHT altered the expression of 10 genes in LCC9: 5 downregulated and 5 upregulated. We note that 17 genes showed lower expression in LCC 9 than MCF-7 cells (Table V). Conversely, 31 genes showed higher expression in LCC9 than MCF-7 cells (Table VI). 
Table II. Genes with increased expression following treatment with $\beta$-D-glucan, $\mathrm{E}_{2}$ and/or 4-OHT in MCF-7 endocrinesensitive breast cancer cells.

\begin{tabular}{lcccr}
\hline Symbol & $\begin{array}{c}10 \mu \mathrm{g} / \mathrm{ml} \\
\beta \text {-D-glucan }\end{array}$ & $\begin{array}{c}50 \mu \mathrm{g} / \mathrm{ml} \\
\beta \text {-D-glucan }\end{array}$ & $\mathrm{E}_{2}$ & $4-\mathrm{OHT}$ \\
\hline BIRC5 & $\mathbf{2 . 6}$ & $\mathbf{3 . 0}$ & $\mathbf{2 . 2}$ & 1.0 \\
BRCA1 & $\mathbf{2 . 7}$ & $\mathbf{2 . 6}$ & $\mathbf{2 . 5}$ & -1.6 \\
BRCA2 & $\mathbf{2 . 3}$ & $\mathbf{2 . 7}$ & $\mathbf{2 . 5}$ & -1.3 \\
CCNA1 & $\mathbf{2 . 1}$ & $\mathbf{2 . 6}$ & $\mathbf{5 . 3}$ & 1.2 \\
CTSD & $\mathbf{2 . 2}$ & 1.7 & 1.8 & 1.0 \\
EGF & 1.2 & -1.2 & 1.3 & $\mathbf{2 . 5}$ \\
GLI1 & 1.7 & 1.2 & -1.6 & $\mathbf{2 . 3}$ \\
GSTP1 & 1.8 & 1.1 & -1.2 & $\mathbf{3 . 5}$ \\
KRT5 & 1.7 & -1.0 & -1.2 & $\mathbf{2 . 2}$ \\
MKI67 & 1.9 & $\mathbf{2 . 6}$ & $\mathbf{2 . 2}$ & 1.1 \\
NME1 & 1.7 & 1.8 & $\mathbf{2 . 1}$ & -1.2 \\
PGR & $\mathbf{3 . 8}$ & $\mathbf{2 . 9}$ & $\mathbf{2 . 9}$ & -1.2 \\
PTGS2 & $\mathbf{2 . 5}$ & 1.8 & 1.9 & 1.1 \\
RASSF1 & $\mathbf{4 . 0}$ & $\mathbf{3 . 8}$ & $\mathbf{2 . 2}$ & $\mathbf{3 . 2}$ \\
SERPINE1 & 1.3 & 1.4 & $\mathbf{2 . 0}$ & $\mathbf{2 . 4}$ \\
TP73 & 1.2 & -1.2 & -1.3 & $\mathbf{6 . 5}$ \\
\hline SFI & & & & \\
\hline
\end{tabular}

Values in bold are greater than the 2-fold cut off in the Breast Cancer PCR array (PAHS-131Z, SABiosciences).

Table III. Genes with decreased expression following treatment with $\beta$-D-glucan, $\mathrm{E}_{2}$ and/or 4-OHT in LCC9 endocrine-resistant breast cancer cells.

\begin{tabular}{lcccc}
\hline Symbol & $\begin{array}{c}10 \mu \mathrm{g} / \mathrm{ml} \\
\beta \text {-D-glucan }\end{array}$ & $\begin{array}{c}50 \mu \mathrm{g} / \mathrm{ml} \\
\beta \text {-D-glucan }\end{array}$ & $\mathrm{E}_{2}$ & $4-\mathrm{OHT}$ \\
\hline ADAM23 & 1.2 & -1.6 & 1.2 & $\mathbf{- 2 . 3}$ \\
BRCA2 & -1.4 & -1.6 & $\mathbf{- 2 . 3}$ & $\mathbf{- 2 . 4}$ \\
CDH13 & $\mathbf{- 2 . 5}$ & -1.8 & $\mathbf{- 2 . 6}$ & -1.8 \\
CDKN1C & $\mathbf{- 2 . 4}$ & -1.4 & -1.6 & $\mathbf{- 3 . 0}$ \\
CTNNB1 & -1.4 & $\mathbf{- 2 . 1}$ & -1.7 & $\mathbf{- 2 . 1}$ \\
ID1 & 1.6 & 1.2 & -1.7 & $\mathbf{- 2 . 4}$ \\
\hline
\end{tabular}

Values in bold are greater than the 2-fold cut off in the Breast Cancer PCR array (PAHS-131Z, SABiosciences).

Confirmation of select changes in breast cancer gene expression by $q R T-P C R$. To determine if the changes detected in the PCR array after treatment of MCF-7 and LCC9 cells with $\beta$-D-glucan were reproducible by qRT-PCR, five gene targets were selected for verification: RASSF1, CTNNB1, IGFBP3, ESR2 (ER $\beta$ ), and $A R$ (Tables I-III, V and VI). 18S was used for normalization and was not significantly different between the two cell lines or with $\beta$-D-glucan treatment (data not shown). The rationale for selecting these genes for follow-
Table IV. Genes with increased expression following treatment with $\beta$-D-glucan, $\mathrm{E}_{2}$ and/or 4-OHT in LCC9 endocrine-resistant breast cancer cells.

\begin{tabular}{lcccc}
\hline Symbol & $\begin{array}{c}10 \mu \mathrm{g} / \mathrm{ml} \\
\beta \text {-D-glucan }\end{array}$ & $\begin{array}{c}50 \mu \mathrm{g} / \mathrm{ml} \\
\beta \text {-D-glucan }\end{array}$ & $\mathrm{E}_{2}$ & 4-OHT \\
\hline EGF & 1.8 & $\mathbf{5 . 1}$ & $\mathbf{4 . 6}$ & $\mathbf{2 . 1}$ \\
GLI1 & $\mathbf{4 . 9}$ & $\mathbf{7 . 4}$ & $\mathbf{3 . 3}$ & $\mathbf{8 . 3}$ \\
HIC1 & 1.4 & 1.4 & 1.6 & $\mathbf{2 . 5}$ \\
IGF1 & $\mathbf{5 . 6}$ & 1.4 & 1.7 & $\mathbf{2 . 9}$ \\
IGFBP3 & $\mathbf{2 . 0}$ & $\mathbf{2 . 0}$ & $\mathbf{2 . 9}$ & 1.1 \\
PTGS2 & $\mathbf{2 . 2}$ & 1.2 & 1.7 & 1.1 \\
TWIST1 & -1.2 & -1.1 & 1.5 & $\mathbf{3 . 7}$ \\
\hline
\end{tabular}

Values in bold are greater than the 2-fold cut off in the Breast Cancer PCR array (PAHS-131Z, SABiosciences).

Table V. Genes with lower expression in LCC9 endocrineresistant vs. MCF-7 endocrine-sensitive breast cancer cells.

\begin{tabular}{lr}
\hline Symbol & Fold \\
\hline$A B C G 2$ & -35.2 \\
$B C L 2$ & -2.1 \\
$C C N D 2$ & -2.0 \\
$C D K N 1 A$ & -5.0 \\
EGF & -2.6 \\
EGFR & -9.1 \\
GATA3 & -4.1 \\
ID1 & -2.2 \\
IGF1R & -2.5 \\
IGFBP3 & -25.7 \\
JUN & -5.5 \\
KRT18 & -3.9 \\
KRT8 & -4.6 \\
$M G M T$ & -2.5 \\
PLAU & -2.0 \\
SLC39A6 & -3.7 \\
THBS1 & -14.1 \\
\hline
\end{tabular}

All genes included show $>2$-fold changes in the Breast Cancer PCR array (PAHS-131Z, SABiosciences).

up is based on their regulation by $\beta$-D-glucan in the PCR array: RASSFl was increased in MCF-7 ( $\mathrm{E}_{2}$ and 4-OHT also increased $R A S S F 1$, Table II); CTNNB1 was decreased in MCF-7 and LCC9; IGFBP3 and ESR2 were increased in LCC9; $A R$ was decreased in MCF-7. Further rationale is based on their roles in breast cancer. RASSF1A is a tumor suppressor gene that is downregulated by hypermethylation in various human cancers including breast cancer $(20,21)$. $C T N N B 1$ encodes $\beta$-catenin, an adherens junction protein 
Table VI. Genes with higher expression in LCC9 endocrineresistant vs. MCF-7 endocrine-sensitive breast cancer cells.

\begin{tabular}{|c|c|}
\hline Symbol & Fold \\
\hline$A B C B 1$ & 2.1 \\
\hline$A D A M 23$ & 11.4 \\
\hline BIRC5 & 5.9 \\
\hline$B R C A 1$ & 2.8 \\
\hline$B R C A 2$ & 7.2 \\
\hline CCNAI & 78.0 \\
\hline $\mathrm{CDH} 13$ & 4.3 \\
\hline$C D K 2$ & 4.1 \\
\hline$C D K N 1 C$ & 2.3 \\
\hline$C D K N 2 A$ & 2.1 \\
\hline CST6 & 2.1 \\
\hline$E S R 2$ & 2.1 \\
\hline GLII & 2.2 \\
\hline GSTP1 & 28.2 \\
\hline $\mathrm{HICl}$ & 4.0 \\
\hline$I G F 1$ & 2.1 \\
\hline IL6 & 2.1 \\
\hline KRT5 & 2.1 \\
\hline$M A P K 1$ & 4.4 \\
\hline$M M P 2$ & 2.1 \\
\hline$M M P 9$ & 3.0 \\
\hline$M Y C$ & 3.6 \\
\hline$P G R$ & 4.5 \\
\hline PRDM2 & 2.2 \\
\hline PTEN & 5.2 \\
\hline RASSF 1 & 2.1 \\
\hline SERPINE1 & 85.4 \\
\hline$S F R P 1$ & 2.1 \\
\hline TWIST 1 & 5.1 \\
\hline$V E G F A$ & 2.6 \\
\hline$X B P 1$ & 3.7 \\
\hline
\end{tabular}

All genes included show >2-fold changes in the Breast Cancer PCR array (PAHS-131Z, SABiosciences). that plays a critical role in cellular adhesion and intercellular communication which also translocates to the nucleus to activate genes whose promoters contain binding sites for Tcf/Lef (22). Activation of the Wnt/ $\beta$-catenin pathway plays a role in breast tumorigenesis $(23,24)$. Insulin-like growth factor (IGF) binding protein 3 (IGFBP3) is a major carrier of IGF1 and IGF2 in circulation and IGFBP3 levels are reduced in breast cancer patients, giving rise to higher free IGF1 levels and poor prognosis $(25,26)$. IGFBP3 also stimulates or inhibits normal and neoplastic breast cell proliferation by stimulating EGFR activation or stimulating apoptotic effector proteins $(27,28)$. $\mathrm{E}_{2}$ stimulates IGFBP3 expression in MCF-7 cells (29) and both $\mathrm{E}_{2}$ and 4-OHT increased IGFBP transcript expression in MDA-MB-231 triple negative breast cancer cells transfected with ER $\alpha$ (30). When IGFBP3 was transfected into LCC9 endocrine-resistant breast cancer cells, it was shown, by co-immunoprecipitation, to interact with the 78-kDa glucose regulated protein (GRP78), which is highly expressed in LCC9 and other endocrine-resistant breast cancer cells (31), and to dissociate caspase 7 from GRP78, thus sensitizing LCC9 cells to growth inhibition by fulvestrant (ICI 182,780) (32). Increased AR expression is found in tamoxifen-resistant breast tumors and overexpression of AR in MCF-7 cells caused the cells to become resistant to growth inhibition by tamoxifen (33).

The increase in RASSF1 transcript expression (Table II) was reproducibly increased by treatment with $\beta$-D-glucan, $\mathrm{E}_{2}$ and 4-OHT in MCF-7 cells (Fig. 7). The inhibition of $C T N N B 1, I G F B P 3$ and $A R$ (Table I) by $\beta$-D-glucan in MCF-7 cells was confirmed; however, $\mathrm{E}_{2}$ and 4-OHT did not significantly inhibit the expression of these genes (Fig. 7), a result different from that detected in the PCR array. Since qRT-PCR is the accepted standard to compare transcript levels, these data suggest that $\mathrm{E}_{2}$ and 4-OHT may not significantly inhibit $C T N N B 1, I G F B P 3$ and $A R$ in MCF-7 cells with 24 h of treatment. In fact, $C T N N B 1$ ( $\beta$-catenin) transcript expression was statistically increased by $4-\mathrm{OHT}$ in MCF-7, although only by 0.5-fold (Fig. 7).

CTNNB1 ( $\beta$-catenin) expression was decreased by $\beta$-D-glucan in a concentration-dependent manner in LCC9

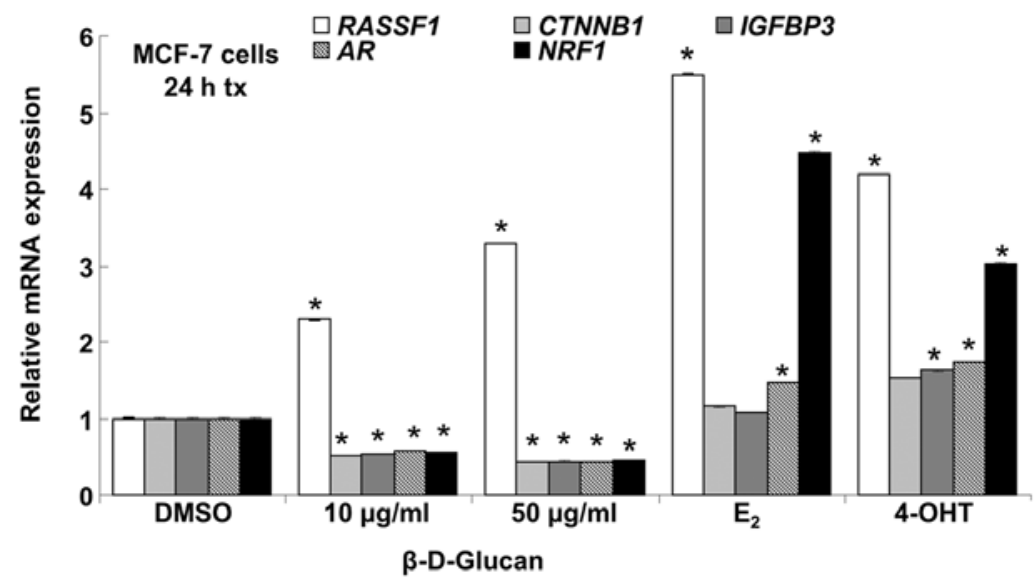

Figure 7. Quantitative real-time PCR analysis of select targets regulated by $\beta$-D-glucan in MCF-7 cells. Cells were grown in phenol red-free IMEM $+5 \%$ DCC for $48 \mathrm{~h}$ prior to addition of DMSO (vehicle control), $10 \mathrm{nM} \mathrm{E}_{2}, 100 \mathrm{nM} 4-\mathrm{OHT}$ or the indicated concentrations of DMSO-dissolved $\beta$-D-glucan for $24 \mathrm{~h}$. qPCR for each target gene was normalized to $18 \mathrm{~S}$ rRNA and values were compared to fold expression in vehicle (DMSO)-treated MCF-7 cells. Values are the average of triplicate determinations \pm SEM within one experiment. 
A

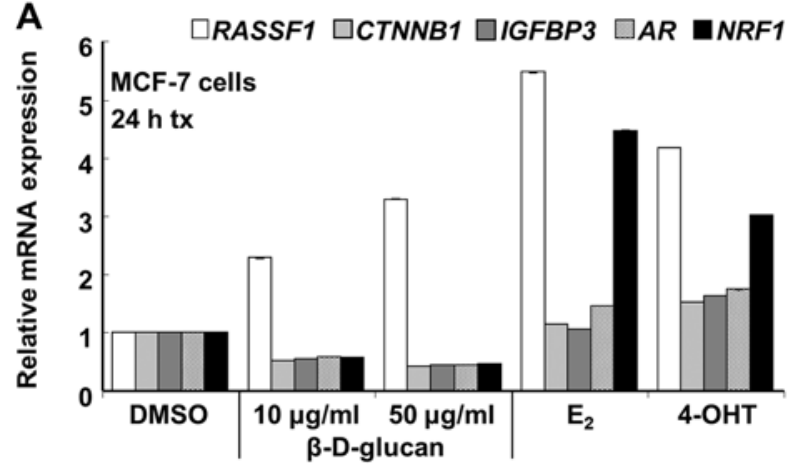

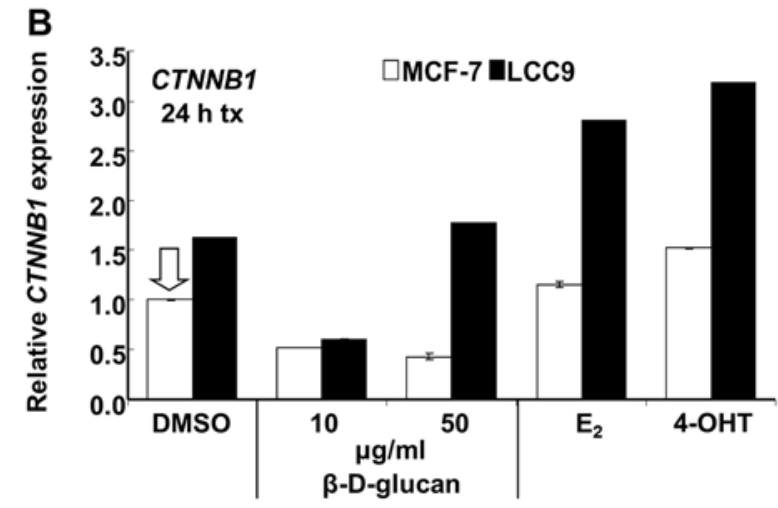
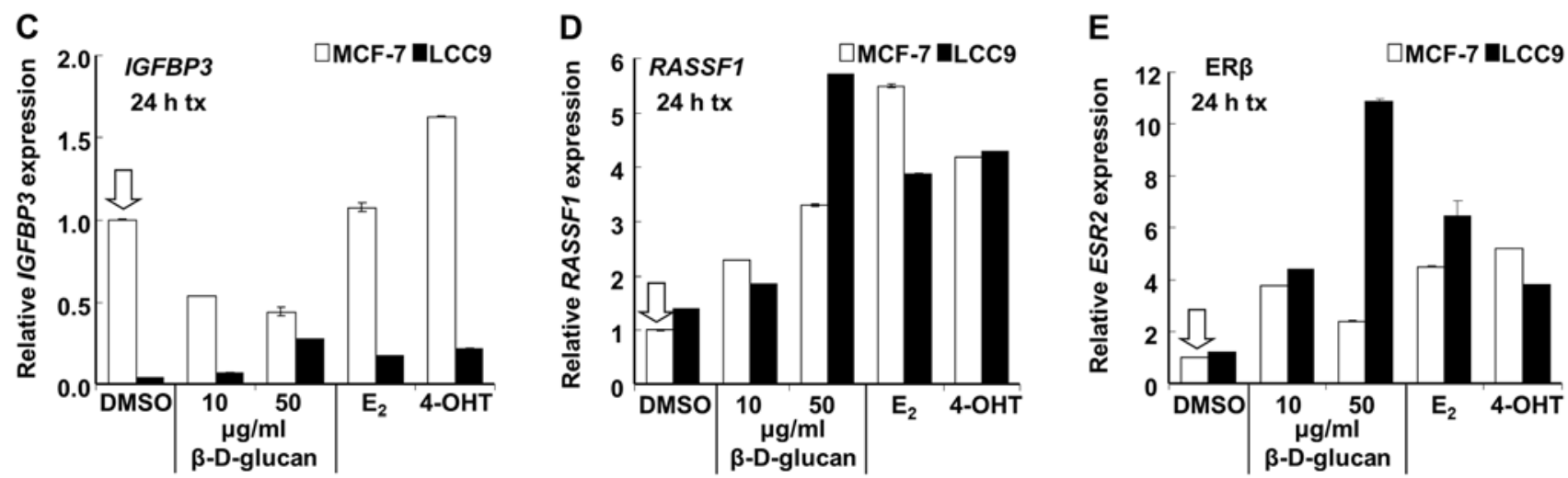

Figure 8. Quantitative real-time PCR analysis of select targets regulated by $\beta$-D-glucan in MCF-7 and LCC9 cells. Cells were grown in phenol red-free IMEM $+5 \%$ DCC for $48 \mathrm{~h}$ prior to addition of DMSO (vehicle), $10 \mathrm{nM} \mathrm{E} 2,100 \mathrm{nM} 4-\mathrm{OHT}$ or the indicated concentrations of DMSO-dissolved $\beta$-D-glucan for $24 \mathrm{~h}$. qPCR for each target gene was normalized to $18 \mathrm{~S}$ and values were compared to fold expression in vehicle (DMSO)-treated MCF-7 cells. Values are the average of triplicate determinations \pm SEM within one experiment. (A) RASSF1, CTNNB1, IGFBP3, AR and NRF1 transcript expression in MCF-7 cells relative to DMSO control. (B) CTNNB1, (C) IGFBP3, (D) RASSF1 and (E) ESR2 (ER $\beta$ ) transcript expression in MCF-7 and LCC9 cells relative to DMSO control.

in the PCR array (Table III) and by $10 \mu \mathrm{g} / \mathrm{ml} \beta$-D-glucan as assessed by qRT-PCR (Fig. 7). However, $50 \mu \mathrm{g} / \mathrm{ml}$ $\beta$-D-glucan, $\mathrm{E}_{2}$ and $4-\mathrm{OHT}$ increased $C T N N B 1$ in LCC9 cells. CTNNBI basal expression was $\sim 63 \%$ higher in LCC9 than MCF-7 (Fig. 8A), although this was not detected in the PCR array (Table VI). $\beta$-catenin mRNA and protein expression is increased in another tamoxifen-resistant cell line derived from MCF-7 cells (34) and in breast tumors (35). The increase in $C T N N B 1$ transcript expression with $\mathrm{E}_{2}$ and 4-OHT was significant in both MCF-7 and LCC9 cells, although the fold-response, 1.7- and 2-fold respectively, compared to basal (DMSO), was higher in LCC9 cells. This increase in $\beta$-catenin expression would be expected to interact with and increase TCF/LEF1 target gene expression in these cells, a pathway contributing to breast cancer progression (23).

AR (androgen receptor, AR, NR3C4) expression was reduced by $\beta$-D-glucan in MCF-7 cells while $\mathrm{E}_{2}$ and 4-OHT slightly increased AR expression.

We confirmed that $\beta$-D-glucan inhibited NRF-1 transcription in MCF-7 cells (Figs. 6 and 7) whereas $\mathrm{E}_{2}$ and 4-OHT increased NRF-1 expression, as previously reported $(19,36)$. Basal NRF-1 transcript expression was higher in LCC9 cells and was increased by $\beta$-D-glucan and inhibited by $E_{2}$ and 4-OHT (Fig. 8B).

Expression of IGFBP3 (insulin-like growth factor binding protein 3) was 25.7-fold lower in LCC9 than MCF-7 (Table V). This result was confirmed by qRT-PCR (Fig. 8C). This is consis-
A
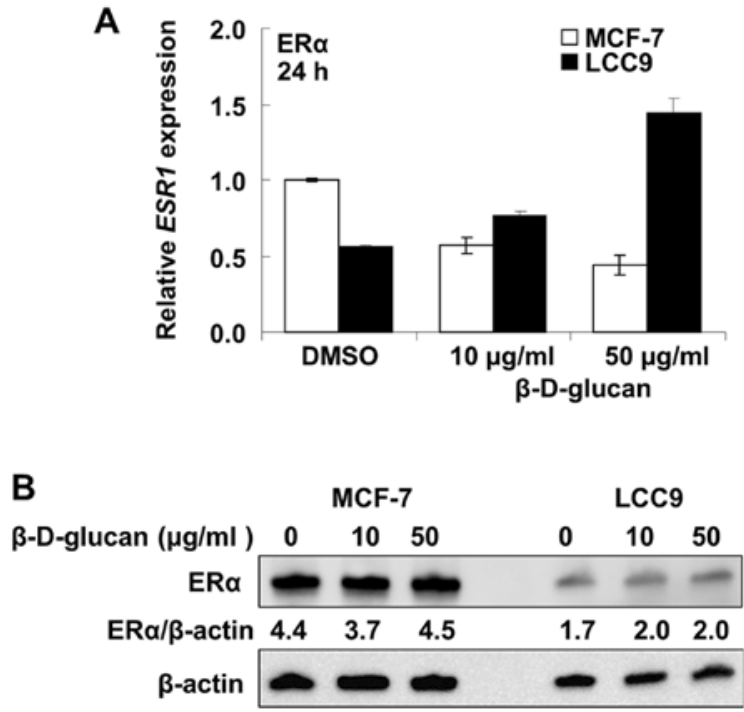

Figure 9. $\beta$-D-glucan affects ER $\alpha$ expression in MCF-7 and LCC9 cells. Cells were grown in phenol red-free IMEM + 5\% DCC-stripped FBS for $48 \mathrm{~h}$ prior to addition of DMSO (vehicle control) or 10 or $50 \mu \mathrm{g} / \mathrm{ml}$ $\beta$-D-glucan dissolved in DMSO for $24 \mathrm{~h}$. (A) ESR1 transcript levels were measured by qPCR relative to $18 \mathrm{~S}$ and are the average of triplicate determinations \pm SEM within one experiment. Values are relative to MCF-7 cells treated with DMSO showing that ER $\alpha$ mRNA expression is lower in LCC9 relative to MCF-7 cells. (B) Whole cell extracts (30 $\mu \mathrm{g}$ protein) were separated on $10 \%$ SDS-PAGE gels and the resulting western blot was probed with ER $\alpha$ antibody and the full length $66 \mathrm{kDa} \mathrm{ER} \alpha$ band is shown. The PVDF membrane was stripped and re-probed for $\beta$-actin for normalization. Values are the $\mathrm{ER} \alpha / \beta$-actin ratio. 
tent with a previous report that IGFBP3 protein secretion was reduced in tamoxifen-resistant LY2 and ZR-75-9a1 cells (37). IGFBP3 (which sequesters IGF) was increased by $\beta$-D-glucan and $\mathrm{E}_{2}$ in LCC9 cells (Table IV). These results were confirmed by qRT-PCR. 4-OHT also increased IGFBP3 in LCC9 cells. In MCF-7 cells, $\beta$-D-glucan inhibited IGFBP3 transcript expression whereas 4-OHT increased IGFBP3 expression.

ESR2 (ER $\beta$ ) and RASSF1 (Ras-association domain family protein 1) showed higher expression in LCC9 than MCF-7 cells in the PCR array (Table VI). This may be surprising since $E R \beta$ inhibits the proliferative activity of $\operatorname{ER} \alpha$ (38) and $R A S F F 1$ is a tumor suppressor gene whose inactivation by hypermethylation of a $\mathrm{CpG}$ island in the gene promoter (39) has been implicated in a wide variety of sporadic human cancers, including breast cancer (20). Results were confirmed by qRT-PCR (Fig. 8D and E). As in MCF-7 cells, $\beta$-D-glucan, $\mathrm{E}_{2}$ and 4-OHT increased RASSF1 expression in LCC9 cells (Fig. 8E). In contrast to the increase in $\mathrm{ER} \beta, \beta$-D-glucan reduced ESRl (ER $\alpha)$ mRNA transcript levels in MCF-7 cells and increased ER $\alpha$ mRNA expression in LCC9 cells (Fig. 9A). $\mathrm{ER} \alpha$ protein expression was unaffected (change $<10 \%$ ) by $\beta$-D-glucan treatment in MCF-7 cells and increased $\sim 17 \%$ in LCC9 cells (Fig. 9B).

\section{Discussion}

Multiple mechanisms contribute to acquired endocrine resistance in breast cancer and new therapies are needed to prevent disease recurrence (2). Here we report that DMSO-solubilized $\beta$-D-glucan inhibited the proliferation of endocrine-sensitive MCF-7 and endocrine-resistant LCC9 and LY2 breast cancer cell lines, but did not inhibit the proliferation of MDA-MB231 TNBC cells. Notably the $\mathrm{IC}_{50}$ values for the breast cancer cell lines were significantly lower than that for MCF-10A immortalized breast epithelial cells. We also report that $\beta$-D-glucan increases cell death in both MCF-7 and LCC9 cells with more death in LCC9 versus MCF-7 cells at $1 \mu \mathrm{g} / \mathrm{ml}$ $\beta$-D-glucan. We found that $10 \mu \mathrm{g} / \mathrm{ml} \beta$-D-glucan increased the $B A X / B C L 2$ ratio in both MCF-7 and LCC 9 cells, but that increase was not sustained at $50 \mu \mathrm{g} / \mathrm{ml} \beta$-D-glucan. Given the decrease in NRF-1 transcription with $\beta$-D-glucan, it is possible that $\beta$-D-glucan is inhibiting mitochondrial function due to toxicity at the $50 \mu \mathrm{g} / \mathrm{ml} \beta$-D-glucan concentration. Further studies will be required to probe mechanisms of cell death in response to $\beta$-D-glucan. We had hoped that $\beta$-D-glucan would synergize with 4 -OHT to inhibit breast cancer cell proliferation, but it did not. These findings agree with the lack of effect of $\beta$-D-glucan and TAM in DMBAinduced mammary tumors (17).

A previous study reported that water-soluble $\beta$-glucan extract from the mycelia of Poria cocos inhibited MCF-7 cell viability with an $\mathrm{IC}_{50}$ of $400 \mu \mathrm{g} / \mathrm{ml}$ (7). Others reported no inhibition of cell viability, measured by MTT assay, using Clitocybe alexandri and Lepista inversa mushroom extracts dissolved in boiling water, but when dissolved in methanol or ethanol, MCF-7 cells were inhibited with an $\mathrm{IC}_{50}$ of $20-80 \mu \mathrm{g} /$ $\mathrm{ml}$, depending on which solvent and which mushroom extract was tested (40). Our data are in agreement with a lack of inhibitory activity of $\beta$-glucan dissolved in water, and indicate that anti-proliferative activity in MCF-7 cells $\beta$-glucan depends on solubilization in an organic solvent. Future studies are needed to identify the active components of the DMSO-solubilized $\beta$-D-glucan.

HEK-293 cells showed a non-monotonic or possible 'U-shaped' dose response to $\beta$-D-glucan in which there was a slight inhibition at a low concentration $(10 \mu \mathrm{g} / \mathrm{ml})$, but increasing concentrations resulted in stimulation of cell proliferation. U-shaped or other non-monotonic dose-responses, referred to as 'hormesis', have been reported in studies of a variety of chemotherapeutics, cytokines, rosiglitazone and other clinically used drugs (41), endocrine-disruptors (42), and phytoestrogens indicating that 'compounds in a cellular context, can have opposite effects at different concentrations' (43). Mechanistically, the mechanism for the lack of linear response in HEK-293 cells is unknown, but we may speculate that at lower $\beta$-D-glucan concentrations a higher affinity antiproliferative response is triggered whereas at higher concentrations, i.e., a lower affinity response, there is an increase in cell proliferation which appears to reach saturation.

A PCR array identified potential breast cancer-associated genes regulated by $\beta$-D-glucan and selected genes were verified by qRT-PCR. AR (NR3C4) expression was reduced by $\beta$-D-glucan in MCF-7 cells. There is one report that AR overexpression in MCF-7 cells reduced ER $\alpha$ and caused cells to become tamoxifen-resistant (33). Chromatin immunoprecipitation sequencing (ChIP-seq) and microarray expression profiling has revealed significant cross-talk in gene regulation between AR and ER $\alpha$ in ZR-75-1 human breast cancer cells (44). The role of AR suppression by $\beta$-D-glucan on the $\beta$-D-glucan inhibition of cell proliferation in MCF-7 cells is unknown and may be investigated in future studies.

$\beta$-D-glucan, $\mathrm{E}_{2}$ and 4-OHT increased RASSF1 expression in MCF-7 and LCC9 cells. A reduction in RASSF1 has been shown to correlate with tamoxifen resistance (45) and the ability of $\beta$-D-glucan to increase RASSF1 expression may correspond to the observed inhibition of cell proliferation and increase in cell death. Further studies will be required to determine the downstream targets regulated by $\beta$-D-glucan-induced RASSF1. Likewise, the increase in ER $\beta$ mRNA in LCC9 cells treated with $\beta$-D-glucan is another logical follow-up for this study to further characterize the mechanisms by which $\beta$-D-glucan inhibits breast cancer cell proliferation in vitro.

\section{Acknowledgements}

This study was performed in the lab of C.M.K. and was supported by National Institute of Health (NIH) R01 DK053220 to C.M.K. Z.M.T.J. was supported by a fellowship from the Iraq Science Fellowship Program for her time in the USA. L.M.L. was supported by National Institute of Environmental Health Sciences (NIEHS) T32 ES011564.

\section{References}

1. Ring A and Dowsett M: Mechanisms of tamoxifen resistance. Endocr Relat Cancer 11: 643-658, 2004.

2. Martin L-A, Pancholi S, Farmer I, Guest S, Ribas R, Weigel M, Thornhill A, Ghazoui Z, A'Hern R, Evans D, Lane H, Johnston S and Dowsett M: Effectiveness and molecular interactions of the clinically active mTORC1 inhibitor everolimus in combination with tamoxifen or letrozole in vitro and in vivo. Breast Cancer Res 14: R132, 2012. 
3. Saraswat-Ohri S, Vashishta A, Vetvicka V, Descroix K, Jamois F, Yvin JC and Ferrieres V: Biological properties of $(1 \rightarrow 3)$-betaD-glucan-based synthetic oligosaccharides. J Med Food 14: 369-376, 2011

4. Bohn JA and BeMiller JN: $(1 \rightarrow 3)-\beta$-d-Glucans as biological response modifiers: a review of structure-functional activity relationships. Carbohydr Polym 28: 3-14, 1995.

5. Kim HS, Hong JT, Kim Y and Han SB: Stimulatory effect of beta-glucans on immune cells. Immune Netw 11: 191-195, 2011

6. Chan G, Chan W and Sze D: The effects of beta-glucan on human immune and cancer cells. J Hematol Oncol 2: 25, 2009.

7. Zhang M, Chiu LC, Cheung PC and Ooi VE: Growth-inhibitory effects of a beta-glucan from the mycelium of Poria cocos on human breast carcinoma MCF-7 cells: cell cycle arrest and apoptosis induction. Oncol Rep 15: 637-643, 2006.

8. Brunner N, Boulay V, Fojo A, Freter CE, Lippman ME and Clarke R: Acquisition of hormone-independent growth in MCF-7 cells is accompanied by increased expression of estrogen-regulated genes but without detectable DNA amplifications. Cancer Res 53: 283-290, 1993.

9. Brunner N, Boysen B, Jirus S, Skaar TC, Holst-Hansen C, Lippman J, Frandsen T, Spang-Thomsen M, Fuqua SA and Clarke R: MCF7/LCC9: an antiestrogen-resistant MCF-7 variant in which acquired resistance to the steroidal antiestrogen ICI 182,780 confers an early cross-resistance to the nonsteroidal antiestrogen tamoxifen. Cancer Res 57: 3486-3493, 1997.

10. Bronzert DA, Greene GL and Lippman ME: Selection and characterization of a breast cancer cell line resistant to the antiestrogen LY 117018. Endocrinology 117: 1409-1417, 1985.

11. Davidson NE, Bronzert DA, Chambon P, Gelmann EP and Lippman ME: Use of two MCF-7 cell variants to evaluate the growth regulatory potential of estrogen-induced products. Cancer Res 46: 1904-1908, 1986.

12. Chen J-Q and Russo J: ER[alpha]-negative and triple negative breast cancer: molecular features and potential therapeutic approaches. Biochim Biophys Acta 1796: 162-175, 2009.

13. Gregory PA, Bert AG, Paterson EL, Barry SC, Tsykin A, Farshid G, Vadas MA, Khew-Goodall Y and Goodall GJ: The miR-200 family and miR-205 regulate epithelial to mesenchymal transition by targeting ZEB1 and SIP1. Nat Cell Biol 10: 593-601, 2008.

14. Vetvicka V and Vetvickova J: beta1,3-Glucan: silver bullet or hot air? Open Glycosci 3: 1-6, 2010.

15. Wyrębska A, Gach K, Lewandowska U, Szewczyk K, Hrabec E, Modranka J, Jakubowski R, Janecki T, Szymański J and Janecka A: Anticancer activity of new synthetic $\alpha$-methylene$\delta$-lactones on two breast cancer cell lines. Basic Clin Pharmacol Toxicol:2013 Aug 19, 2013 (Epub ahead of print). doi: 10.1111/ bept.12120.

16. Crawford AC, Riggins RB, Shajahan AN, Zwart A and Clarke R: Co-inhibition of BCL-W and BCL2 restores antiestrogen sensitivity through BECN1 and promotes an autophagy-associated necrosis. PLoS One 5: e8604, 2010.

17. Mansour A, Daba A, Baddour N, El-Saadani M and Aleem E: Schizophyllan inhibits the development of mammary and hepatic carcinomas induced by 7,12 dimethylbenz(alpha) anthracene and decreases cell proliferation: comparison with tamoxifen. J Cancer Res Clin Oncol 138: 1579-1596, 2012.

18. Scarpulla RC: Nuclear control of respiratory chain expression by nuclear respiratory factors and PGC-1-related coactivator. Ann NY Acad Sci 1147: 321-334, 2008.

19. Ivanova MM, Luken KH, Zimmer AS, Lenzo FL, Smith RJ, Arteel MW, Kollenberg TJ, Mattingly KA and Klinge CM: Tamoxifen increases nuclear respiratory factor 1 transcription by activating estrogen receptor $\beta$ and AP-1 recruitment to adjacent promoter binding sites. FASEB J 25: 1402-1416, 2011.

20. Dammann R, Schagdarsurengin U, Seidel C, Strunnikova M, Rastetter M, Baier K and Pfeifer GP: The tumor suppressor RASSF1A in human carcinogenesis: an update. Histol Histopathol 20: 645-663, 2005.

21. Shukla S, Mirza S, Sharma G, Parshad R, Gupta SD and Ralhan R: Detection of RASSF1A and RARbeta hypermethylation in serum DNA from breast cancer patients. Epigenetics 1: 88-93, 2006.

22. Lin S, Xia W, Wang J, Kwong K, Spohn B, Wen Y, Pestell R and Hung M: Beta-catenin, a novel prognostic marker for breast cancer: its roles in cyclin D1 expression and cancer progression. Proc Natl Acad Sci USA 97: 4262-4266, 2000.
23. Howe LR and Brown AM: Wnt signaling and breast cancer. Cancer Biol Ther 3: 36-41, 2004.

24. Paul S and Dey A: Wnt signaling and cancer development: therapeutic implication. Neoplasma 55: 165-176, 2008.

25. Espelund U, Cold S, Frystyk J, Orskov H and Flyvbjerg A Elevated free IGF2 levels in localized, early-stage breast cancer in women. Eur J Endocrinol 159: 595-601, 2008.

26. Duggan C, Wang CY, Neuhouser ML, Xiao L, Smith AW, Reding KW, Baumgartner RN, Baumgartner KB, Bernstein L, Ballard-Barbash R and McTiernan A: Associations of insulin-like growth factor and insulin-like growth factor binding protein-3 with mortality in women with breast cancer. Int J Cancer 132: 1191-1200, 2013.

27. Martin JL, Lin MZ, McGowan EM and Baxter RC: Potentiation of growth factor signaling by insulin-like growth factor-binding protein-3 in breast epithelial cells requires sphingosine kinase activity. J Biol Chem 284: 25542-25552, 2009.

28. McIntosh J, Dennison G, Holly JMP, Jarrett C, Frankow A Foulstone EJ, Winters ZE and Perks CM: IGFBP-3 can either inhibit or enhance EGF-mediated growth of breast epithelial cells dependent upon the presence of fibronectin. J Biol Chem 285: 38788-38800, 2010

29. Levenson AS, Svoboda KM, Pease KM, Kaiser SA, Chen B, Simons LA, Jovanovic BD, Dyck PA and Jordan VC: Gene expression profiles with activation of the estrogen receptor alpha-selective estrogen receptor modulator complex in breast cancer cells expressing wild-type estrogen receptor. Cancer Res 62: 4419-4426, 2002.

30. Wang D-Y, Fulthorpe R, Liss SN and Edwards EA: Identification of estrogen-responsive genes by complementary deoxyribonucleic acid microarray and characterization of a novel early estrogen-induced gene: EEIG1. Mol Endocrinol 18: 402-411, 2004.

31. Cook KL, Shajahan AN, Wärri A, Jin L, Hilakivi-Clarke LA and Clarke R: Glucose-regulated protein 78 controls cross-talk between apoptosis and autophagy to determine antiestrogen responsiveness. Cancer Res 72: 3337-3349, 2012.

32. Li C, Harada A and Oh Y: IGFBP-3 sensitizes antiestrogenresistant breast cancer cells through interaction with GRP78. Cancer Lett 325: 200-206, 2012.

33. De Amicis F, Thirugnansampanthan J, Cui Y, Selever J, Beyer A, Parra I, Weigel NL, Herynk MH, Tsimelzon A, Lewis MT, Chamness GC, Hilsenbeck SG, Ando S and Fuqua SA: Androgen receptor overexpression induces tamoxifen resistance in human breast cancer cells. Breast Cancer Res Treat 121: 1-11, 2010.

34. Hiscox S, Jiang WG, Obermeier K, Taylor K, Morgan L, Burmi R, Barrow D and Nicholson RI: Tamoxifen resistance in MCF7 cells promotes EMT-like behaviour and involves modulation of beta-catenin phosphorylation. Int J Cancer 118: 290-301, 2006.

35. Fodde $\mathrm{R}$ and Brabletz $\mathrm{T}$ : Wnt $/ \beta$-catenin signaling in cancer stemness and malignant behavior. Curr Opin Cell Biol 19: $150-158,2007$

36. Mattingly KA, Ivanova MM, Riggs KA, Wickramasinghe NS, Barch MJ and Klinge CM: Estradiol stimulates transcription of Nuclear Respiratory Factor-1 and increases mitochondrial biogenesis. Mol Endocrinol 22: 609-622, 2008.

37. Maxwell P and van den Berg HW: Changes in the secretion of insulin-like growth factor binding proteins -2 and -4 associated with the development of tamoxifen resistance and estrogen independence in human breast cancer cell lines. Cancer Lett 139: 121-127, 1999.

38. Thomas $\mathrm{C}$ and Gustafsson $\mathrm{J}-\AA$ : The different roles of ER subtypes in cancer biology and therapy. Nat Rev Cancer 11: 597-608, 2011

39. Pfeifer GP and Dammann R: Methylation of the tumor suppressor gene RASSF1A in human tumors. Biochemistry 70: 576-583, 2005 .

40. Vaz JA, Heleno SA, Martins A, Almeida GM, Vasconcelos MH and Ferreira ICFR: Wild mushrooms Clitocybe alexandri and Lepista inversa: in vitro antioxidant activity and growth inhibition of human tumour cell lines. Food Chem Toxicol 48: 2881-2884, 2010

41. Doñate F, Parry GC, Shaked Y, Hensley H, Guan X, Beck I, Tel-Tsur Z, Plunkett ML, Manuia M, Shaw DE, Kerbel RS and Mazar AP: Pharmacology of the novel antiangiogenic peptide ATN-161 (Ac-PHSCN-NH2): observation of a U-shaped doseresponse curve in several preclinical models of angiogenesis and tumor growth. Clin Cancer Res 14: 2137-2144, 2008. 
42. Vandenberg LN, Colborn T, Hayes TB, Heindel JJ, Jacobs DR, Lee D-H, Shioda T, Soto AM, vom Saal FS, Welshons WV, Zoeller RT and Myers JP: Hormones and endocrine-disrupting chemicals: low-dose effects and nonmonotonic dose responses. Endocr Rev 33: 378-455, 2012.

43. Almstrup K, Fernandez MF, Petersen JH, Olea N, Skakkebaek NE and Leffers H: Dual effects of phytoestrogens result in u-shaped dose-response curves. Environ Health Perspect 110: 743-748, 2002.
44. Need EF, Selth LA, Harris TJ, Birrell SN, Tilley WD and Buchanan G: Research resource: interplay between the genomic and transcriptional networks of androgen receptor and estrogen receptor $\alpha$ in luminal breast cancer cells. Mol Endocrinol 26: 1941-1952, 2012.

45. Fiegl H, Millinger S, Mueller-Holzner E, Marth C, Ensinger C, Berger A, Klocker H, Goebel G and Widschwendter M: Circulating tumor-specific DNA: a marker for monitoring efficacy of adjuvant therapy in cancer patients. Cancer Res 65: 1141-1145, 2005. 